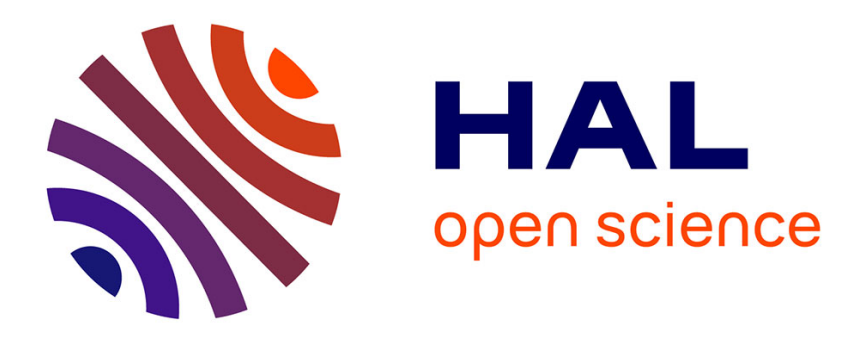

\title{
Cultural politics and spiritual making of anthropologists
}

Albert Doja

\section{To cite this version:}

Albert Doja. Cultural politics and spiritual making of anthropologists. Reviews in Anthropology, 2004, 33 (1), pp.73-94. 10.1080/713649341 . halshs-00406236

\section{HAL Id: halshs-00406236 \\ https://shs.hal.science/halshs-00406236}

Submitted on 13 Oct 2009

HAL is a multi-disciplinary open access archive for the deposit and dissemination of scientific research documents, whether they are published or not. The documents may come from teaching and research institutions in France or abroad, or from public or private research centers.
L'archive ouverte pluridisciplinaire HAL, est destinée au dépôt et à la diffusion de documents scientifiques de niveau recherche, publiés ou non, émanant des établissements d'enseignement et de recherche français ou étrangers, des laboratoires publics ou privés. 
Published in:

Reviews in Anthropology, Vol. 33, pp. 73-94

Copyright (C) 2004 Taylor \& Francis Inc.

ISSN: 0093-8157 print

Routledge

DOI: $10.1080 / 00988150490273699$

\title{
Cultural Politics and Spiritual Making of Anthropologists
}

\author{
Albert Doja
}

Duijzings, Ger. Religion and the Politics of Identity in Kosovo. London: Hurst, New York: Columbia University Press, 2000. xv +238 pp. including maps, photos, and index. $\$ 60.00$, cloth; $\$ 19.50$ paper.

Trix, Frances. Spiritual Discourse: Learning with an Islamic Master. Philadelphia: University of Pennsylvania Press (Conduct and Communication Series), 1993. xi +189 pp. including index. \$30.00 cloth; $\$ 18.50$ paper.

Ethnographic studies of religion, stuck somewhere between ethnocentrism and literalism (especially in the case of Islam), have brought little distinctive anthropological analysis to bear successfully on the practical realities and political ideologies of religions. On the other hand, the popular assertion that certain ethnic groups, having had conflicts over centuries, will continue to fight with one another, is but an idea fuelled by numerous media reports and scholarly publications that stress the historical nature of conflict, much in the same way as the idea that Islam and modernity are somehow adversarial. It is frustrating that during times of uncertainty such essentialist explanations of difference continue to hold significant weight. As long as "history" functions as a screen behind which the interests of political or religious leaders are hidden, ethnic or cultural conflicts will continue to appear intractable. Furthermore, there are the modern views of the nation-state and all its institutionalized mythologies, which over the last one hundred years have confused, erased, desecrated, and demolished our understanding of local definitions and categories of group identity articulated in everyday life. Yet, it is only by exploring how group political

ALBERT DOJA is a Senior Research Fellow at the University of Limerick, Ireland.

Address correspondence to Albert Doja, College of Humanities, University of Limerick, Ireland: E-mail: albert.doja@ul.ie 
identities are constructed, by disentangling the relationships between anxiety, threats, and group identity responses, that the paths for conflict amelioration can be elucidated.

In quite different but original books, the authors of the works reviewed in this essay try to raise the standard of scholarship and address some of the issues outlined above. In Spiritual Discourse, Frances Trix develops a proper sociolinguistic study of the meanings of and means for transmitting Islamic spirituality and worldview. In Religion and the Politics of Identity in Kosovo, Ger Duijzings argues that Kosovo is not a simple case of irreconcilably distinct communities where religion is alleged to play a central role, but is rather an example of complex, historically informed interchanges between loosely defined "communities" established on the basis of loosely specified notions of religious, linguistic, and/or ethnic identity.

\section{POLITICS OF IDENTITY AND THE PRACTICE OF ETHNOGRAPHY}

Duijzings's book, especially his introduction, offers a clear critical reading of the events and tensions that plagued Kosovo over the last hundred years. Of great interest are the details that Duijzings brings to his study of various, seemingly marginal groups in Kosovo; these details shed light on important facts of identity strategies of interethnic and interdenominational relations. Duijzings reveals the paucity of Western understanding of Kosovo, which has often been presented as an area steeped in historical conflict. This conflict is generally cast as two-sided (Serb versus Albanian or Orthodox versus Muslim), with two antagonistic groups clashing and centuries-old hatreds being unleashed. The prevailing notion that "Serbs" and "Albanians" are distinct and largely antagonistic groups is not only a simplified version of historical and political facts but also a nationalist distortion and represents the outcome of agitation rather than a description of root causes for the conflict.

While it has become commonplace to treat Albanian and Muslim cultural identity as interchangeable, suggesting cultural homogeneity, Duijzings documents the different facets of both Muslim and Albanian identity. By deconstructing these "communities," he confronts the essentialist claim that Serbs and Albanians are locked in conflict due to an irreconcilable hostility between Orthodox Christianity and Islam. Actually, in the Balkans there are considerable cultural criss-crossings between Islam and Christianity; in fact, Duijzings makes it clear that the groups of the region are not historically predisposed towards conflict. Quite to the contrary, the various religious and ethnic groups reflect continuous interaction with one another. It was only after the first Balkan War, in 1912, that relations between 
Albanians and Serbs really turned sour, much of this because the Serb side proceeded with threats of forced assimilation. Duijzings's argument seems to be that there is after all a great deal more in common between Serbs and Albanians than one might suppose and that the radicalization of Kosovo was not inevitable.

Duijzings persuasively argues that "the formation and transformation of ethnic and religious identities is determined by wider political developments" (p. 22). Identities are political constructs in which state and religious regimes play crucial roles in their formation. Instead of regarding religion and politics as separate domains, Duijzings sees them as intimately connected formations of power. In peripheral societies like Kosovo where the official authority was often only partial, political and religious elites found particularly fertile ground for manipulating ethnic identities. For this aptly defined "frontier society," where ethnic and religious identifications are flexible, he illustrates how group boundaries are more fluid and less institutionalized. Even if local, regional, and religious identities remain very significant, the dichotomy between city and country is notable and ethnic identifications are linked to religious identity. In addition, state violence is not unrelated to processes of identity construction.

Although now part of history, the processes of "ethnic unmixing" and creation of stable one-dimensional identities through violence that have eliminated much of the fluidity and interrelatedness of Kosovo society is a case that is especially instructive. Duijzings asserts that Kosovo's problems are not ethnic in origin but have been ethnicized by political and religious leaders "who want easy political gain" (p. 204). If we continue to understand the conflicts in the former Yugoslavia as exclusively ethnic, we will remain largely blind to the underlying political motivations and goals set by the parties that have the most to gain from conflict. Political and religious elites attempting to hold or seize power and prestige can misdirect attention from their efforts by hiding behind the veil of mass ethnic strife.

The point is not that Duijzings is mounting a counterintuitive argument, but rather that he shows, especially in the introduction to the book, that the banal generalizations which have been endemic and so widespread in the West about the enduring character of the enmity between Serbs and Albanians (as between Christians and Muslims in the Balkans) have no basis in fact, and the reality is considerably more complex. The assertions that Kosovo's population has a long history of sharing cultural traits including language, religious rites, and spatial identifications will go a long way in dispelling what most authors of the Balkans like to assert at best as mysteries and at worst as crude fixations. As other reviewers have noticed, ${ }^{1}$ the very fact that Duijzings intently tries to demonstrate cross-cultural contact taking place in a number of localities is indicative of how much these fixations 
dominate the literature. It is time to toss these misconstructions in the theoretical and empirical garbage bin of nonsense. Unfortunately, it is only now that ethnographers and social scientists have started to produce articulate challenges to these hazardous and dangerous myths.

Duijzings's book is therefore most welcome, especially its introduction, even if it seems insufficiently grounded in the empirical work related to the chapters that follow. As some reviewers have remarked, while some chapters go back twelve years, the introduction was the last and most polished thing that Duijzing wrote for this collection. Though the introduction can initially excite the reader, the rest of the book can disappoint since the sophistication and intellectual maturity exhibited in the introduction is clearly lacking in much that follows. In fact, the initial excitement may encourage the reader to neglect the rich material that could have been present in a better work. The underlying problem with the entire collection is its problematic methodology, which often seems to favor a reliance on a flawed body of secondary literature rather than a combination of extensive fieldwork and a critical reading of sources. This is regretful because in the introduction Duijzings goes to great lengths to articulate a dynamic in the region that is completely at odds with what much of the literature of the past promotes. Perhaps this is due to the fact that this is not a book in the classical sense; as Duijzings states in the preface, "this is not the book I intended to write" (p. ix). In the early 1990s his research project considered what seemed to be a stable community, Letnica, a Catholic, ethnic-Croat enclave in Kosovo near Macedonia. The discussion about Letnica, however, is restricted to just the first chapter of the book (pp. 37-64). His ambitious project probably suffered from the accelerated events in Kosovo during the Milosevic era, when nearly the entire Croat population of Letnica became refugees in Croatia. Thus, as suggested by other reviewers, the uneven quality of presentation and argument among the case studies discussed in the book may be largely due to the fact that Duijzings was only able to do extensive fieldwork in just this one case. Certainly, the unfortunate realities of the 1990s linked to the nature of identity politics might have dramatically changed the projects of many anthropologists, though not necessarily the projects of all.

Sifting through a body of secondary sources, Duijzings forcibly tries to fit the material into what he correctly knows about the nature of identity. Unfortunately, his overreliance on the work of respected Balkan commentators such as Hasluck (1929) and Malcolm (1998) is unhealthy. Both produced some of the best professional secondary resources you could hope to use for Kosovo. However, to assume authority while making unsubstantiated statements is a dangerous trap that Duijzings might have clearly understood. They cannot provide us with the analytical foundation 
for what has been, ultimately in their case, an attempt to historicize a phenomenon that today is rather difficult to monitor anthropologically. In addition, while some reviewers have noted that his analysis seems to be problematic, as it is based not on field observations but on an old secondary literature that does not give sufficient details and makes the comparison difficult (Clayer, 2001, p. 306), others point out that it is remarkable how many authoritative sources are totally ignored in parts of Duijzings's book (Norris, 2002, p. 226).

However, Duijzings's scholarship especially runs into trouble when he relies heavily on local publications, from newspapers to post-1986 Serbian "social science," which makes the reading of his case studies terribly frustrating, as he uses too often these politically charged and blatant propaganda sources to substantiate realities that are central to his argument. This is especially evident in his brief discussion of "the making of Egyptians" in Kosovo and Macedonia (pp. 132-156). Even if some reviewers believe that this "short chapter conveys and explains the transience and political function of identity in the Balkans better than most of the voluminous tomes on the subject" (Bellamy, 2001, p. 197), others aptly point out that Duijzings relies excessively on the nationalist discourse of journalists and scholars, which "reflects a dangerous process of legitimizing 'points of view' when they in fact are scandalously false and contrived" (Blumi, 2000, p. 129). More importantly, some classic and very dangerous nationalist mythologies (especially those that are all too often referenced with no qualification in Duijzings' book, such as the Serbian fascist propaganda about Albanian efforts to force assimilation) promulgate accusations that have never been substantiated with documentary evidence and fly in the face of history. As with much of this type of literature, these assertions are typically made by people whose authority stems from their political allegiance to nationalist projects. Duijzings himself is far too careful to outwardly subscribe to the premise of theories of this kind. Nevertheless, by incorporating this material so heavily into the content, the impact of his analysis is blurred and confused. The danger of adopting this flawed literature while attempting to contribute to the study of shifting identity is that it implicitly accepts the foundation - if not the content-of highly distorted suppositions.

In that context, instead of subscribing to charges of Albanian "hegemony" and "genocide" (!), there are far more productive and helpful ways of exploring individual motivations and cultural consequences of adopting one particular identity or another.

What is clear, however, is that Duijzings is at his best when he does not depend on secondary literature but is informed by his own fieldwork and an intimate knowledge of the situation on the ground. A focus on marginal activities at the grassroots level helps Duijzings make important observations 
about the nature of identity and the role of religion in conflict and cohesion in Kosovo. By considering examples of identity development in Kosovo that most Western scholars overlook, several of the studies, in one way or another, demonstrate the incomplete nature of identity conversion.

For instance, Duijzings examines ethnically mixed pilgrimages and ambiguous sanctuaries as a laboratory of identity, where you can see both fission and fusion at work. In such religious events Catholics, Orthodox, and Muslims come together at each other's sanctuaries and shrines, and rituals are shared and group identities are blurred. While showing that Catholic and Muslim Albanians have enjoyed largely unproblematic relations, he describes the history of crypto-Catholicism in Kosovo and explains how it united Albanians, making Islam and Christianity both part of their common identity. Duijzings can also speak knowledgeably about Albanian dervishes, the revival of popular Sufism, and the Bektashis. The latter, a religious brotherhood that is dominant in Albania, is also present in Kosovo and Western Macedonia.

Finally, all of these cases together with their introduction make Duijzings's book an original contribution to the literature on identity politics in the Balkans, making it possible to elucidate contemporary problems of nationalism. Rather than casting ethnic conflict as a retreat to "ancient hatreds," this book views these violent moments as social ruptures, thus providing insight into the motivations and political formations that rush into the vacuums that accompany social dislocations. Ideas about ethnic separation were transmitted by religious/political elites and reproduced in the form of group identity formation. The divides between Serb and Albanian as between Christian and Muslim were contingent upon the immediate nature of social threats and the political-social dislocations that accompanied them.

\section{RELIGIOUS POLITICS AND NATIONALIST PROJECTS}

Though religion constitutes just one factor among many that contributes to the development of a sense of belonging to a larger group, most identity scholars consider it an identity marker that divides one group from another. The practice of religion, like any cultural marker, is a ritual linked to the historical contingencies of a particular moment. As Duijzings explains, religious practices in the region have shifted over time, altering the definitions of group identity. He reminds us that for Albanians "religion is almost irrelevant in official political life" (p. 159); that Albanian nationalism is not clothed in religious terms; and that Kosovo's Muslims were not supported by Muslims from elsewhere in the Balkans. This challenges the notion that 
knowing an individual's religious identity facilitates placing that person within a given ethnic identification or conflict. Duijzings's work is particularly useful in deconstructing the notion of a monolithic Islamic identity in the Balkans. By tracing the internal divisions between the Albanian dervish orders and the Bosnian ulemas (the officially sanctioned Islamic Association) in the former Yugoslavia (pp. 106-131), he shows that what specialists of the literature call "Balkan Islam" (Popovic, 1986; Bougarel \& Clayer, 2001) is instead manifested in a complicated variety of expressions that give rise to a number of identities.

Duijzings draws attention to the political realities exacerbating the differences between these religious groups. First and foremost, he documents a split among Muslims in Kosovo, that is, between those who turn toward Sarajevo as the center for religious guidance and those who do not. The former are often referred to as "Muslim Slavs" associated with Bosnian Muslims to the north; these Islamic practitioners speak Serbian as their mother tongue and do not consider themselves to be ethnically Albanian. There is a second split among Muslims along the confessional Sunni/ Shiite divide. Yet, Sunni Islam is associated with the Muslim Slavs of Sarajevo. The Islamic Association wielded all the political power from Sarajevo, while the dervish orders were largely based in underdeveloped rural areas that had fared badly at the end of the Balkan wars and conclusion of each World War. Not surprisingly, Kosovo sheikhs conducted open polemics in the 1970s and resisted efforts by Sarajevo Islamic authorities to weaken the dervish orders in Kosovo. These polemics only subsided when federal state authorities intervened in 1979. The fact that Bosnian Muslims generally preferred to marry Bosnian Croats or Serbs instead of Albanian Muslims is symptomatic of the same state of affairs.

If some specialists in the area consider the opposition between popular Albanian Sufism in Kosovo and Slavic orthodox Sunni Islam in Bosnia as a "distorted caricature," (Clayer, 2001, p. 307) the contradictions are indeed deeply rooted, going far beyond specialist conceptions caught in a mixture of literalism and dreadful statisticizing which means absolutely nothing. These contradictions have rather a political, social, and moral significance, which are better expressed in ethnic or religious discourses. As Bosnian Muslims held privileged positions regarding Islamic matters under the Yugoslav system, the proliferation of Sufism in Kosovo can be interpreted as an attempt by Albanian Muslims to reassert their autonomy in the religious sphere.

In discourses related to Muslim religious revival, be it confraternal or otherwise, one recurrently finds nationalist motives, which better illustrate the necessity of considering such a powerful mobilizing force in the role that religious leaders claim they play in this field. 
Yet, in the last two chapters (pp. 157-175), Duijzings attempts a comparative textual analysis of what he asserts are Albanian and Serb examples of how religious symbolisms infiltrate "national" imaginations. He argues that Albanian nationalists at one time might have attempted to infuse their cause with religious elements largely drawn from Bektashism, in particular from elements drawn from a long epic poem in twenty-five cantos, the Qerbelaja (published in 1898), which retells the saga of Shiism by the well-known nineteenth-century Albanian poet Naim Frashëri.

Naim Frashëri was one of the most eminent thinkers and leading figure of Albanian Bektashism, Albanian romanticism, and the Albanian national movement. His Bektashi epic has to be judged in the context of another monumental epic, the History of Skanderbeg, in which Frashëri narrates the exploits, successes and failures of the Albanian national hero against the Ottoman invaders, and which is held to be his most famous and greatest poetic aspiration. Even though both were published the same year and were written on the same style, one grounded on Muslim mythology and Eastern mysticism, the other on classic mythology and Christian symbolism, it is only the latter epic that became the poem of Albanian national side. The martyrs of Karbala, quite contrary to historical evidence and Eastern tradition, owe much to the heroism of the romantic era, including Frashëri's own poetic portray of Skanderbeg (Norris, 1993, p. 182).

In the formulation and argumentation of nationalist ideology, Frashëri made use of both religious and realist, pantheist and gnostic conceptions. Among other things, he openly suggested and theorized the reconciliation of religion with the idea of the nation. However, it is an exaggeration to argue, as Duijzings (p. 167) does, that Naim Frashëri's attempt has been to bridge the religious divide of Albanians by proposing Bektashism as the national religion of Albanians. This view seems to stem from an uncritical reliance on secondary compilations of literary histories (e.g., Mann, 1955; Elsie, 1995) found throughout Duijzings's book. As a matter of fact, this belief seems simply impossible and even quite absurd to those with a minimal knowledge of the Albanian context. The Bektashis were a small minority quite marginalized within Albanian society, especially before the spread of the national movement; Naim Frashëri was certainly not blind to this fact. The relationship of religion and national ideas in Frashëri's conceptions has been very often uncritically investigated by scholars camped on both sides of either religious (Qazimi, 1996) or nationalist (Xholi, 1998) lines. There is reason to believe, however, that Naim Frashëri didn't intend so much to provide Albanians with a unique religion, but rather to make nationalist ideas acceptable to Albanians regardless of religious affiliation.

The problem is not so much whether this has been, as Duijzings argues, a failed attempt to bridge the religious divide between Albanians by 
promoting a secular national cause that incorporates some heterodox Bektashi elements within it. Taking Naim Frashëri's epic reproduction of the Battle of Karbala and situating it on comparative grounds with state and church-produced literature that recreates and embellishes the mythology of the Kosovo Battle in Serbia, is in itself a problematic issue in methodological and analytical terms. Duijzings finds both have much in common: each have been portrayed through epic song and folk verse, and both record a lost battle where righteous forces were overcome by evil ones and the main hero was sacrificed, leading to the necessity for followers to accept suffering as a step to redemption and a revolt against tyranny. Overall, Duijzings believes both lent similar weight to the growth of Albanian and Serb nationalisms during the nineteenth century, respectively.

Still, as some reviewers note, excepting the partly religious nature of both myths, they cannot be compared either in terms of content or their elaboration and diffusion. Duijzings recognizes the lack of a deeply rooted cultural tradition as the reason for the failure of Naim Frashëri's epic to become a powerful political symbol in Albanian nationalism. In contrast, what has made the Kosovo Battle myth so extremely powerful is its making rooted in folklorism and the church culture of Serbian nationalism. Duijzings (pp. 176-202) has correctly understood it this way, as is suggested in his chapter on the Serbian folk-epic of Kosovo. Although the Kosovo myth was created in Serbia and never resonated in Kosovo itself, throughout the twentieth century it provided for Serbs a set of roles with which to sort into proper categories ambiguous or overlapping identities in Kosovo. The Serbian Kosovo myth and epic poetry grew out of a long elaboration of oral and church traditions; their religious content was closely tied to the culture harbored by the Orthodox Church, a powerful institution that is always influential in Serbian nationalist ideology. Actually, even after the downfall of communism and federalism in Yugoslavia, the Serbian Orthodox Church revitalized nationalism by carrying around Serbia Lazar's bones for reconsecration. Relations between the church and state were enormously strengthened. Even the military murderers were transformed into heroes through epic songs, a process aptly labeled as "gusle laundering" (p. 199), while Serb paramilitary leaders were compared to Milosh Obilic, the main hero of the Kosovo Battle. ${ }^{2}$

The tendency to equate Serbian and Albanian nationalism is not only unjustified but is actually a dangerous ambush in which Serbian nationalist agitators still try to entrap public and scholarly opinions. In fact, the political instrumentality of the Serbian myths of the Battle of Kosovo is not exactly commensurable with Naim Frashëri's Qerbelaja, but rather with other types of political folklorism and pseudoculturalist projects serving either chauvinistically or ideologically charged nationalisms. Examples of this sort could be 
found, for instance, in the communist propaganda of Eastern and Central Europe when cultural and folkloric traditions were instrumental for justifying and magnifying the "authentic" foundations of the political and ideological regime, as I have shown elsewhere for the case of communist Albania (Doja, 1998). Other anthropologists have suggested a similar argument (e.g., Gossiaux, 1995). Another parallel with the Serbian Kosovo mythologies can be found in Hitler's propaganda campaign of the $1930 \mathrm{~s}$ and early 1940s when German Volkskunde traditions were instrumental in promoting the sinisterly reputed Nazi ideology. But to compare Frashëri's national ideology to Serbian nationalism, as Duijzings does, is like comparing Herder to Hitler!

While the Battle of Kosovo was instrumental for Serbian nationalism as the mythologizing and embellishment of a local, historical, and factual reality, Naim Frashëri on the other hand uses the drama of Karbala as a local and historical metaphor of a mythical and worldview ethical. In this sense, the parallel between Albanian and Serbian national ideology, if any, seems to be in difference instead of similarity. There are two different, opposed conceptualizations that give way, after instrumental transformations, to a number of single utterances, which share some similar details in style and content but are irrelevant for any relational comparison. When you compare such single utterances, you do not compare them on a superficial, linear one-to-one basis, but only with respect to their relative setting in the whole field of constructed nationalisms, and their relative difference or similarity with all other relevant actual occurrences within the same field. Both types of transformations are variants of the same pattern, but there are differences in the form and content of their conceptualization of prerequisites and outcomes.

What is lacking here is the analytical and anthropological insight to understand that the poetic and intellectual speculations of Naim Frashëri, which retell the saga of Shiism as the religion of victims of persecution, are relevant because they have been instrumental in shaping theological ideas with gnostic and dualist conceptions that would have reasonably made it possible for the Bektashi religion to join with Albanian national ideology. Indeed, it would be necessary to argue this link, especially through the analysis of the organizational and theological character of Bektashism as a mystical, heterodox order throughout its historical transformations. Only to the extent that contest and liberation ideologies are or must be articulated with hierarchization of covenantal structures of divine mediation can we understand not only the difficulty in explaining why Albanian nationalism generally lacked strong religious attachments, but also the special "failed" relation of Bektashi religion to Albanian nationalism through Naim Frashëri's poem Qerbelaja. At this point it is necessary to 
discuss the organizational and theological character of Bektashism and its historical transformations, which brings me to Frances Trix's book.

\section{SPIRITUAL DISCOURSE AND WRITING CULTURE WHILE LEARNING FROM ISLAMIC MASTERS}

The focus of Frances Trix's study is one lesson with an Albanian-American Islamic master, Baba Rexheb, leader of the Bektashi order at the tekke (Islamic lodge or monastery) of Detroit in Michigan. The lesson is rich in poetry and parable, narrative and face-saving humor. As Trix seeks to understand how Baba teaches, she conceptualizes the lesson in terms of episodes and dialogic patterns. Baba teaches through a highly personalized, recursive sort of language "play" that engenders constant attention while constantly evoking an evergrowing past and identity building through narrative.

Trix's assumption is that a description of a lesson with Baba will shed the most light on the master/disciple relationship since she was faced with the puzzle of how to view the relationship of master and disciple in the context of analyzing a lesson. Previous Islamic studies have preserved the poetry of murshids and certain biographical details, but they have also tended to take for granted the process of their teaching. All the same, previous interactional studies, such as those between interviewer and client, teacher and student, or doctor and patient, have also taken the relationships for granted. Other discourse studies have tended to fossilize transcriptions of interactions, but in this case, if learning indeed took place, a developmental approach was necessary.

Actually, even though anthropologists and scholars of religious studies have appreciated the importance of oral interaction in the transmission of spiritual knowledge for quite some time now, the conceptual framework and methodology for its analysis have been lacking. Correspondingly, for scholars of discourse and interaction, Trix's study contributes the central concept of linguistic convergence that operates not at the level of speech community but rather at the level of dialogic encounter and that occurs most often among people who have interacted for a long time. To the extent that she focuses on the discursive practice rather than on what else it might refract, Trix's strategy-by focusing on linguistic praxis-preserves the object of analysis without either essentializing its terms or rewriting them as sociology. This marks the arrival of sophisticated sociolinguistics, and specifically of ethnopoetic methods of parsing discourse in religious studies that shift from adjudicating indigenous discourse to studying its features and practice. 
Her analysis elicits the multiple layers of reference and performance conveyed in the discursive practices. In a stunningly apt match of method to object, Trix takes you through the interactive structure of the lesson, showing how it calls on expressive forms and discussing what she calls "keying," which fuses intertextuality to intersubjectivity. Discussion of Bektashi frames of learning rounds out a process she identifies as "attunement in linguistic interaction," which she defines for the purposes of her study as "an increasing coordination through playful recollecting of dialogue with another" (p. 150). Attunement is based on a recursive process and involves the development of a "shared reference system" along the lines of what Wittgenstein referred to as language games. On the whole, Trix relates attunement to the notions of linguistic convergence, hermeneutical appropriation, and structural coupling.

Trix's study has clearly been informed by lucid theoretical and methodological aims, and there is much to be learned in her book. Discourse analysis and ethnography are now sophisticated research methods used in fieldwork by both linguist and sociocultural anthropologists. The object of research could certainly be the research method itself, for as the recent tendencies in both subdisciplines have made abundantly clear, reflexive ethnography and discourse analysis are crucial to current developments in anthropological theory. Trix's book definitely addresses important issues in this respect. Processes of knowledge acquisition, such as the development of competence in discourse strategies and the linguistic fine-tuning of conversational cohesion, the control of topic, genre, and language variety to convey attitudes and relationships, or code-switching and lexico-syntactic mirroring as strategies of social cohesion, are some of the topics covered in the book which linguistic anthropologists and discourse analysis specialists are indeed much more capable of recognizing. ${ }^{3}$

Yet, despite the methodological insights provided, the book is centered on the structure of the learning process, not on the content of Sufi knowledge or the practice of mysticism and the meaning of relationships and activities usually implied. This is true even though Trix refers to the "motif of sudden illumination" (p. 11) in the learning process, a phrase frequently used in the literature in reference to spiritual enlightenment and the "mystical union" of God and the seeker. Certainly she experienced a series of "sudden illuminations" in which she broke through to new levels of understanding of the process of learning with her master, of the relationship between them, and of what the ideal relationship between master and disciple is or must be. But if you are looking for a description of the transcendent union with God and what it means for her and her master, you will be disappointed. In that sense, as others have noted, her Spiritual Discourse is misleading. 
I consider it interesting, however, to focus the discussion on the very content of the object of her study, which is the meaning of the relations between master and disciple, since her main assumptions concern exactly this relationship. In other words, I would like to question the extent to which her conceptual framework and methodology, if adequately reconsidered, could provide a better understanding of Sufism and Bektashi religious conceptions in particular, and of mystical and heterodox orders in general. This understanding, in turn, could be conceptualized externally in terms of the societal, personal, and ritual meanings it presumes. This seems important because the foundation of Bektashi and all Sufi orders is exactly the system and relationship of master and disciple. In the Bektashi milieux, time is mostly spent making mubabet, which is talking with each other, and chanting or reading nefes, the Bektashi spiritual hymns and poems. In this way they learn how to be a talib ("one who seeks, who strives after"), the name given to the follower, the aspirant, or the disciple of a murshid (the master, the spiritual guide, or, roughly, the "teacher"). Among Bektashis, as the importance of the talib and murshid relationship is overriding, the next identity frame is also the name of one's murshid. In the Bektashi world of discourse, in parables and narratives, poetry and nefes, the centrality of the relationship with the murshid is the norm. The murshid himself, the master, is also a talib, a disciple, for each murshid is a talib of his own murshid (p. 75).

Before becoming an assistant and now an associate professor of anthropology at Wayne State University, Frances Trix had been a talib for twenty years, learning Bektashism from her own murshid and probably aiming to become a Bektashi. Her study of the evolving relationship between talib and murshid is analogous to the process of language learning, where language is understood as personally linked games and the main game is the sharing of nefes, whose linkages have theological significance. In nefes, this "breath of spirit," the feelings and devotion toward one's particular murshid, are endlessly evoked and elaborated. Frances Trix believed the nefes could thus be seen as a particular Bektashi language of the talib/murshid relationship. The Bektashis consider the power of a nefes to be the actualization of the relationship with the murshid, for the inspiration to compose a nefes comes from one's own murshid.

An important issue mentioned in Trix's book is the fact that the Albanian spiritual master repeatedly made the point for his talib, Frances Trix in this instance, that Sunni Islam considers the relationship of human beings to God as a direct one "without intermediary." The critical message was that Bektashism, in contrast to Orthodox Islam and Christianity, adheres strongly to the belief in intermediaries between humans and God, with the murshid being such an intermediary. The buildup to this message was first a 
quick likening of Christianity with Sunni Islam, and an equally swift contrasting of these religious forms with Sufi Islam. The new understanding that emerged reinforced the message of the murshid being an intermediary, and more specifically an intercessor. Through many connections, by repeatedly telling and retelling narratives and adages, chanting nefes and making mubabet, the message that the murshid is the intermediary between human beings and God is evoked, reformulated and memorably forged throughout Frances Trix's book (see pp. 33, 69-70, 95, 120-125, 127, 131, 151). This in turn gives the talib an expanded understanding of the murshid, both as intercessor and as agent of inspiration.

Frances Trix's experiences as a talib can be used to examine the extent to which the murshid-talib relationship contributes to an understanding of Bektashi cultural models. Her story, gracefully and humbly told, is not so much a discourse-oriented ethnography of learning or a sociolinguistic illustration of mysticism, but above all a text that illuminates the process of an interpersonal encounter. Overall what is being passed on is not facts but a relationship and a communication, for the relationship and communication between seeker and master mirrors that of humans and God. In this sense, although Trix's primary aim is not to describe the mystical experience and its social significance, her study gives an intimate and detailed account of the steps that she herself has taken on the Sufi path as led by her master. As such, her study is a rare application of linguistic anthropology to the transmission of spiritual knowledge that makes a significant contribution to our general understanding of Sufism. Her statements are particularly interesting from both points of view: that of the talib learning spiritual knowledge from her own murshid, and that of the anthropologist interpreting this knowledge and writing about culture from a scholarly perspective.

One of the functions of religion as a social system, especially in Christianity and Islam, is to serve as a mediating cultural system of representation between powerless earthly creatures and an all-powerful God located in heaven. Mediation makes it possible for the heavenly divinity to intercede on behalf of humans on earth. Muslims, in particular apologists of Sufism, assert that Islam is more than religion and articulate its techniques and master-disciple relations as reflections of those of God to humans; indeed, these assertions are commonly met with a more social or political ontology.

Definitely in the case of Bektashism the difference for the talib lies in the presence of the murshid as the intermediary between humans and God, while in the case of orthodox Islam or Christianity the relationship is seen as a direct one without intermediary. Frances Trix, as a talib, could not but view the relationship in this way. The learning framework and the position of talib offered her a vague yet all-encompassing scheme in which every narrative and adage must be placed according to theological 
explanations. Yet, the teaching process Trix describes is not a common occurrence in daily life but rather part of those rare instances when one is forced publicly to produce the type of intellectual explanation which daily life does not normally call for. Baba Rexheb, the same Islamic master teaching anthropologist Frances Trix, has managed to publish in print a number of intellectual speculations concerning Bektashism. ${ }^{4}$ Certainly, his erudition is not ideologically and politically charged in the same way as the "social science" publicized by the exponents of Serbian nationalism and on which some analysts unfortunately rely on far too often when explaining Yugoslav wars and Balkan history and politics. Yet, anyone who has read the Islamic master's intellectual speculations is observing the counterpart of what such superinformants as Ogotemmeli or Muchona (as probably all anthropologists know) can manage to do with ideological schemes when their prestige is at stake. This is still nothing more than what Maurice Bloch (1985) calls the expansion of ideology into something which misleadingly looks like an interpretation of the world.

Unfortunately, Frances Trix, the established anthropologist, seems unable to recognize a different meaning for her relationship as a talib other than that advanced by Bektashi ideology. This brings to the forefront what anthropologists know as the danger of "going native," which refers to the possibility of becoming overinvolved with the people being studied to the point of losing the detachment that is essential for the role of analyst.

When linguists and anthropologists are analyzing discourse and making ethnography, it is certainly not merely for the sake of an exclusive self-reflexive methodology and discoursing verbal flow. I believe that in using different kinds of research methods for writing and talking about culture and cultural content the scope of anthropology as a discipline, be it linguistic or political, after all should be a search for cultural meanings and understandings. Otherwise, to use the style of verbal and poetic interaction so highly valued among Bektashis and Albanians, and to paraphrase a pair of Bektashi couplets mentioned by Trix (p. 93), I wonder, are they in search of meaning or are they not, are they writing and talking about culture or are they not?

I suspect a related problem for Frances Trix as for Ger Duijzings is the regrettable tendency of British and American publishers to tolerate a good deal of literature written by authors who are not fluent in the necessary languages, but who nonetheless seem to think that by dressing their stuff up as "political science" or "discourse analysis" they will somehow attain greater wisdom. Duijzings knows Serbo-Croat (he teaches Serbo-Croat Studies in London) but probably not Albanian, as he himself suggests while acknowledging the translation of some original texts by one of his Albanian students (p. 173). Similarly, Frances Trix clearly knows Turkish, as she is able to 
illustrate the mutually developed conventions of interaction that give episodic structure to the lesson through Turkish and English transcriptions and analyses. I first thought that she was also fluent in Albanian as well because in another work she provided a brilliant sociolinguistic analysis of the history of the Albanian alphabet (Trix, 1997). Surprisingly, however, she suggests quite the contrary while describing a lesson where the master "shifted, it appears absent-mindedly, into Albanian"; noticing the shift, Trix gently advances a "request to have him return to Turkish: në turkisht të lutem, in Turkish please" (pp. 110-111). Certainly, you can negotiate your own way through Kosovo and Bektashi surroundings speaking Serbo-Croat or Turkish, but if you also lack extensive fieldwork or are entrapped in the narrow framework of what you have been taught, this becomes a considerable shortcoming, as anyone listening to an Albanian mubabet in Kosovo's cafés or in a Bektashi tekke will have a better chance of knowing what is truly going on.

\section{POLITICAL REVERSAL AND CULTURAL UNDERSTANDINGS}

For a talib the message of the murshid as an intermediary between humans and God is well assessed and clearly understood. Yet, what is lacking in Trix's case is the anthropological intuition that would enable her to recognize the exact meaning of the Bektashi conception of the relationship between humans and God. According to Trix and all apologists of Sufism and Bektashism, the difference between heterodox Bektashism and orthodox Islam and Christianity must be in the Sufi and Bektashi hierarchical, intermediary organizational structure between humans and God through the transmission of mystical gnosis from one's murshid. This amounts to saying that in the case of orthodox Islam and Christianity there is an absence of such a communication or, put another way, that there is the presence of a direct, unmediated communication between humans and God (for a full discussion see Doja, 2001).

It is clear that the relationship between talib and murshid is particularly relevant for understanding Bektashi religious conceptions, but a critical examination of this relationship can be an outstanding opportunity for arguing exactly the opposite of what Bektashi ideology attempts to put forward. As long as heterodox theology developed from common experience of both spiritual knowledge and suffering, it is possible to understand how covenantal structures of divine mediation corresponding to specific stages of Bektashism and Sufism gain a different meaning if the intermediary hierarchy is found in the conceptualization of the divinity or in the organization of the worldly, human society. From this standpoint we can gain a better 
understanding of how and to what extent Bektashism as a mystical, heterodox religion might have been related to Albanian nationalism.

Elsewhere (Doja, 2000) I have argued that the significance of understanding the communication between humans and God lies in the fact that, as Edmund Leach (1972) pointed out, the hierarchical model of religious mediation corresponds to the dogma of orthodox faiths, while the model in which all hierarchies are denied - in its real embodiments-is closely linked to millenarian and mystical beliefs and to the development of heresies and heterodoxies such as those related to Bektashism. The former model may well support an established, hierarchical power, whereas the latter corresponds to an oppressed or deprived minority seeking justification of its revolt against the established authorities. According to this model, the establishment of a political hierarchy within society goes hand in hand with the insertion of a unified conception of divinity, i.e., a pure monotheism within the theological system. On the other hand, a visible hierarchical conception of the divinity goes along with egalitarian politics in society. The conception of a relational equality, derived from the idea that people are equal in their relations with the divinity, is effectively present alongside an ideology of substantial egalitarianism among human beings.

The character of Bektashism and all Sufi or Shiite groupings of Islam display, in their religious structure and theological doctrines, a cultural system corresponding first to the model of religious mediation in which all hierarchies are denied. This view is not contradicted by Frances Trix's study; on the contrary, her conceptual framework and methodology, if adequately reconsidered, lends considerable weight to it. The only thing is that, as I argued elsewhere in full details (Doja 2003), when the members of the previously persecuted religious minority have already acquired a degree of political respectability within society at large, the subjective and millenarian doctrines of heterodoxy and liberation theology fade into the background. In the end, as it happened with Ottoman and Albanian Bektashism correspondingly, the chances are that the heirs of the heretic and heterodox promoters of spiritual reform and social movement will turn into followers and faithful defenders of a legitimate authority. They will become the spokespeople for an institutionalized orthodoxy whose support will be sought by the political regime.

In the peak of its heyday during the seventeenth century, Bektashismmaintaining a strong central organization with affiliated village groups limited to Anatolia and its European provinces_-even claimed to be a Sunni order (Trimingham, 1971, p. 80). However, it was in fact very unorthodox and regarded as a Shiite order due to its reverence for the House of Ali. The fact that the Bektashis were rarely attacked on grounds of doctrine or innovations is directly related to their association with the Janissaries and Ottoman 
authority. In turn, the officials of the order clearly gave their loyalty to the Sunna of the Prophet as a necessary stage in their code of discipline.

It was under the political patronage of independent Albania, however, that Albanian Bektashism, recognized by the highest governmental authorities, came to be a nationally and internationally structured ecclesiastic institution. The organization of the Order became increasingly structured, improving its methods of recruitment of followers and the appointment of its hierarchy. Because of explicit political circumstances, as specialists have shown through abundant documentary evidence (Clayer, 1990, pp. 47-67), the hierarchical pattern of the organizational structure of Bektashism in Albania reached a very peculiar expression not only in terminological, local terms, but also in a more sophisticated and clear-cut ecclesiastical as well as political hierarchy, which perhaps surpassed limits observed in Ottoman context.

Furthermore, here again the final stage of the hierarchical and centralized organization coincides with the establishment of orthodox religious and political power. As generally within Sufism in similar conditions, conformity to the legal establishment began from the moment the religious Bektashi leaders felt the need to support their statements with prophetic sayings, and when they felt it was necessary to express conformity with the revealed Law of orthodox Islam (Shariat). During the period of independent Albania, representatives of the hierarchy of the Albanian Bektashi clergy again expressed themselves against assertions that often tended to consider the order of Bektashis as a doctrine of strong syncretism that diverged from orthodox Sunni Islam much more than other Muslim orders. Francis Trix's master Baba Rexheb, for instance, in one of his treatises on Bektashism published in New York, insisted that Bektashi rituals are not in opposition to Sunni Islam, that Bektashism is "inside Islam" and, sometimes, that it is even the "real Islam." Allegations of this kind, fervently claimed by religious scholars or naively justified by seemingly well-intentioned local scholars, may well be noticed by specialists (e.g., Clayer, 1990, pp. 77-78; Norris, 1993, p. 94), but without necessarily explainingor indeed understanding at all-that a deep evolution had been already achieved, not only in organizational and political structures but also in theological and religious conceptions.

On the other hand, the regime sought the support of instituted Bektashism every time, just as it did with other religious denominations, and even took the initiative of imposing and controlling their doctrinal orthodoxy and hierarchical organization. All kinds of intimidations were used to this end, and it is certainly not a mere coincidence that every time that a new regime came to power the highest level of Bektashi hierarchy suffered internal cabinet reshuffles, even leading to repeatedly mysterious murders. With 
the power of communist ideology increasing, all religions-eliminated in 1967-were rendered purely and simply unnecessary. These trials and tribulations, in turn, created new conditions for Albanian Bektashism to once again become the religion of victims of persecution, as it did while sheltered in Cairo or in Michigan where Frances Trix also found her master, before reemerging in Albania in full after the downfall of communism in 1991.

The transition from innovation to conservatism, and the subsequent renewal of innovation, takes on different forms and tones, forming a complex process requiring detailed historical and anthropological analysis of the cultural values and social entities involved. Nevertheless, it is necessary at this point to understand just how and to what extent this kind of political manipulation can really take place in people's minds, which brings me once again to Duijzings's Kosovo case studies, in particular to the case of joint pilgrimages and ambiguous sanctuaries (pp. 65-85).

Typically, pilgrimages in the Balkans have often been characterized by a blurring of formal religious boundaries. A number of examples from the early twentieth century in the Balkans reported by Hasluck (1929), as well as at least three ethnographic examples from the recent history of Kosovo described by Duijzings (pp. 66-78), demonstrate clearly that religious gatherings of different ethno-religious groups need not end in conflict, as long as neither the administration and religious signature nor the cultural dominance of one group over the other becomes an issue. On the other hand, the spontaneous community of believers of different ethno-religious backgrounds can acquire a political and ideological function and can be manipulated by worldly and religious authorities when certain elements are felt to pose a threat to the position and authority of those in control of a devotional regime and to the religious signature of the shrine.

Still, beyond the kind of crossing over that sometimes leads to what Duijzings calls merely "amalgamated traditions" (p. 84), which relies on Hasluck's idea of "ambiguous sanctuaries," some additional analytical directions would have appealed greatly to the anthropologist's imagination. The simple fact of saint veneration implies the existence of groups or individuals hierarchically superior, who attempt to use this position to identify their own legitimacy with the saints so as to implement their own political strategies. A good example of legitimizing this kind of political enterprise is perhaps Peter Brown's (1981) insightful description of the impresarios of saints in late antiquity, which in many respects is similar to the worship of miracleworking saints typical of mystic orders of Islam such as Bektashism. I believe that it is the very cult of saint veneration, related to the tombs of holy men and miracle-working saints, dead or alive, and their association with the qualities and properties of the divine mystical knowledge that, as Trimingham's (1971) pioneering work has demonstrated, paradoxically lead 
to the weakening of the mystical expression, whereas the diversion in the direction of devotion to saints and concentration upon the collective cult of "recollection of God" lead to a continuous hiving off the mass of believers.

Bektashi cultural models, grounded metaphorically and materially in the recurrent founding of the order's communities around newly dominated shrines, both reproduce existing schemas through practice and are tools of self-interest in the hands of religious leaders. The logic revealed appears to be based on conceptions of metaphysical balance and a sacred covenantal relationship between individuals and cultural forces. The foundations are both events and symbols, and as symbols they convey meaning and can be read expressively as well as instrumentally. A kind of closure is implicit here in the sense of a temporally specific convergence of individual intentions and larger structural processes.

This discussion harks back to Bourdieu's work (1972) on habitus and the way in which the immediately experienced properties of social worlds are structured. This is not culture in the usual sense but a powerful mode of cultural production. In its simplest terms it refers to the way in which Muslim symbols and objects have been assimilated in Southeast Europe into a specific practice of Christian religiosity. Certain historical practices of state administrative relationships and political patronage in the area show forms of articulation in which extraneous Muslim forms are reorganized into local strategies and logics of social reproduction. This is not the same as syncretism or hybridity as the terms are often used, since it stresses the nature of the articulation that is dominated by local forms of experience and strategy.

In fact, Hasluck's earlier concept of ambiguous sanctuary" is addressed by a full acknowledgment of "Bektashi propaganda". His evidence of pilgrimages, or that of Durham (another early Balkan traveler) witnessing in 1904 a pilgrimage where "thousands of Christians as well as Bosnian and Albanian Muslims gathered in perfect concord" (Duijzing, p. 77), can very well mask experiences of hierarchization and partial mixing. Duijzings's own observations make it possible to understand that, even in times of peace, the mixing of pilgrimages is but relative. In Gracanica, for example (pp. 66-71), the pilgrimage does not take the same form for Muslim Gypsies and Orthodox Serbs, and the ritual is not really mixed.

New concepts of "competitive sharing" and "antagonistic tolerance" (Hayden, 2002) explain how sacred sites that have long been shared by members of differing religious communities and they may even exhibit syncretistic mixtures of the practices of both may come to be seized or destroyed by members of one of them in order to manifest dominance over the other. This confusion seems to lie at the heart of a critical weakness of most current explanations of nationalist conflict in the Balkans and 
elsewhere. The paradox is that syncretism may be fostered by inequality and seems actually endangered by equality between the groups. In turn, the advantage is that arguments of this kind can lead us to operationalize the link between idiosyncratic cognition and the dynamics of shared culture. This will hopefully help us gain a better idea of the precise mechanics of how individually articulated intentions not only reproduce but also change the cultural system itself.

\section{NOTES}

1. Duijzings's book is reviewed in an impressive number of scholarly and popular journals, including Southeast European Politics; Canadian Slavonic Papers; Islamochristiana; Religion, State \& Society; International Affairs; The Review of International Affairs; Journal of Southern Europe \& the Balkans; Balkanologie; Slavic Review; Slavonic \& East European Review; Ethnic and Racial Studies; Nations and Nationalism; Journal of Islamic Studies; and International Politic.

2. It may be ironic for the Serbian nationalist mythology that Milosh Kopilic, the grand hero who challenged and killed the Ottoman Sultan in the Battle, was, if not Albanian, certainly not a Serb according to the most realistic scholarship reviewed in Malcolm (1998). This puzzle should inform local scholars more about the transformational quality of mythical thought than about historical facts used for nationalist ideologies.

3. Trix's book is reviewed in the American Anthropologist, Language, and the International Journal of Middle East Studies.

4. See his misticizma islame dhe bektashizma, New York, 1970; reprint Tirana, 1995.

5. See his "Ambiguous sanctuaries and Bektashi propaganda", Annual of the British School at Athens, Vol. 20, session 1913-1914, (Reprint in Hasluck, 1929).]

\section{REFERENCES}

Bellamy, A. J. (2001). Review of Religion and the Politics of Identity in Kosovo. International Affairs, 77(1), 197.

Bloch, M. (1985). From cognition to ideology. In R. Fardon (Ed.), Power and knowledge: Anthropological and sociological approaches Edinburgh: Scottish Academic Press, 21-48.

Blumi, I. (2000). Review of Religion and the Politics of Identity in Kosovo. Southeast European Politics, 1(2), 126-130.

Bougarel, X., \& Clayer, N. (Eds.). (2001). Le nouvel Islam balkanique: Les musulmans acteurs du post-communisme (1990-2000). Paris: Maisonneuve \& Larose.

Bourdieu, P. (1972). Esquisse d'une théorie de la pratique. Travaux de droit, d'économie, de sociologie et de sciences politiques, 92. Genève: Droz.

Brown, P. R. L. (1981). The cult of the saints: Its rise and function in Latin Christianity. Haskell Lectures on history of religions, new series, no. 2. Chicago: University of Chicago Press.

Clayer, N. (1990). L'Albanie, pays des derviches: Les ordres mystiques musulmans en Albanie à l'èpoque post-ottomane, 1912-1967. Balkanologische Veröffentlichungen, 17. Berlin \& Wiesbaden: Harrassowitz.

Clayer, N. (2001). Review of Duijzings's Religion and the Politics of Identity in Kosovo. Balkanologie: Revue de l'Association Française d'Études sur les Balkans, 5(1-2), 304-308. 
Doja, A. (1998). Èvolution et folklorisation des traditions culturelles. East European Quarterly, 32(1), 95-126.

Doja, A. (2000). Histoire et dialectique des idéologies et significations religieuses. European Legacy: Journal of the International Society for the Study of European Ideas, 5(5), 663-686.

Doja, A. (2001). An Albanian Bektashi master, discourse ethnography of learning and the spiritual making of an anthropologist: An account on method and content. H-Net Reviews in the Humanities and Social Sciences, 8 , http://www.h-net.org//reviews//showrev.cgi?path = 2451996090546

Doja, A. (2003). Confraternal religion: from liberation theology to political reversal. History and Anthropology, 14(4).

Elsie, R. (1995). History of Albanian literature. East European monographs, no. 379. Boulder, $\mathrm{CO}$ and New York: Columbia University Press.

Gossiaux, J.-F. (1995). Le sens et le verbe: Sur deux modes opposés d'instrumentalisation politique du folklore. L'Homme: Revue Française d'Anthropologie, 35(135), 127-134.

Hasluck, F. W. (1929). Christianity and Islam under the Sultans. Oxford: Clarendon Press.

Hayden, R. M. (2002). Antagonistic tolerance: Competitive sharing of religious sites in South Asia and the Balkans. Current Anthropology, 43(2), 205-231.

Leach, E. R. (1972). Melchisedech and the emperor: Icons of subversion and orthodoxy. Proceedings of the Royal Anthropological Institute of Great Britain and Ireland, 5-14.

Malcolm, N. (1998). Kosovo: A short history. London: Macmillan.

Mann, S. E. (1955). Albanian literature: An outline of prose, poetry, and drama. London: Quaritch.

Norris, H. T. (1993). Islam in the Balkans: religion and society between Europe and the Arab world. London: Hurst.

Norris, H. T. (2002). Review of Duijzings's Religion and the Politics of Identity in Kosovo. Journal of Islamic Studies, 13(2), 225-227.

Popovic, A. (1986). L'islam balkanique: Les musulmans du sud-est européen dans la période post-ottomane. Balkanologische Veröffentlichungen, 11. Berlin \& Wiesbaden: Harrassowitz.

Qazimi, Q. (1996). Ndikime orientale në veprën letrare të Naim Frashërit [Oriental influences in Naim Frashëri's literary opus]. Prishtina, Kosovo: Këshilli i Bashkësisë Islame të Gjilanit.

Sahlins, M. D. (1981). Historical metaphors and mythical realities: Structure in the early history of the Sandwich Islands kingdom. Ann Arbor: University of Michigan Press.

Trimingham, J. S. (1971). The Sufi orders in Islam. Oxford: Clarendon Press.

Trix, Frances. (1997). Alphabet conflict in the Balkans: Albanian and the Congress of Monastir. International Journal of the Sociology of Language, 128, 1-23.

Xholi, Z. (1998). Naim Frashëri midis së kaluarës dhe së sotmes [Naim Frashëri between past and present]. Tirana. 